\title{
DDRT-PCR approaches applied for preeminent results in the isolation of DETs from fish brain tissues
}

\author{
Alves-Costa, FA. ${ }^{a *}$ and Wasko, AP. ${ }^{b}$ \\ anstituto de Ciências da Saúde, Universidade Paulista - UNIP, Rua Luiz Levorato, 20108, \\ CEP 17048-290, Bauru, SP, Brazil \\ bDepartamento de Genética, Instituto de Biociências, Universidade Estadual Paulista - UNESP, \\ Distrito de Rubião Junior, s/n, CEP 18618-970, Botucatu, SP, Brazil \\ *e-mail: fa_alves2003@yahoo.com.br
}

Received: July 16, 2013 - Accepted: September 20, 2013 - Distributed: March 31, 2015

(With 2 figures)

\begin{abstract}
Differential Display (DD) is a technique widely used in studies of differential expression. Most of these analyses, especially those involving fish species, are restricted to species from North America and Europe or to commercial species, as salmonids. Studies related to South American fish species are underexplored. Thus, the present work aimed to describe DD technique modifications in order to improve outcomes related to the isolation of DETs (Differentially Expressed Transcripts), using Leporinus macrocephalus, a large commercially exploited South American species, as a fish design. Different DDRT-PCR approaches were applied to brain samples and the products of the reactions were analyzed on $6 \%$ polyacrylamide gels stained with $0.17 \%$ Silver Nitrate $\left(\mathrm{AgNO}_{3}\right)$. The use of PCR reactions under high stringency conditions and longer oligonucleotides based on VNTR (Variable Number of Tandem Repeats) core sequences led to better results when compared to low stringency PCR conditions and the use of decamer oligonucleotides. The improved approach led to the isolation of differentially expressed transcripts on adult males and females of $L$. macrocephalus. This study indicates that some modifications on the DDRT-PCR method can ensure isolation of DETs from different fish tissues and the development of robust data related to this approach.
\end{abstract}

Keywords: Leporinus macrocephalus, differentially expressed transcripts, VNTR.

\section{Aplicação de abordagens de DDRT-PCR para aprimoramento de resultados no isolamento de DETs a partir de tecido cerebral de peixes}

\begin{abstract}
Resumo
Display Diferencial (DD) é uma técnica amplamente utilizada em estudos de expressão diferencial. A maioria desses estudos envolvendo espécies de peixes está restrita a espécies da América do Norte e Europa ou a espécies comerciais, como os salmoniformes. Estudos relacionados a peixes da América do Sul são ainda pouco explorados. Desse modo, o presente trabalho teve como objetivo descrever modificações na técnica de DD, a fim de melhorar os resultados relacionados ao isolamento de DETs (Transcritos Diferencialmente Expressos), utilizando Leporinus macrocephalus, peixe explorado comercialmente na América do Sul, como espécie para tal delineamento. Diferentes abordagens de DDRT-PCR foram desenvolvidas a partir de amostras de tecido cerebral e os produtos das reações foram analisados em gel de poliacrilamida $6 \%$ corados com $0,17 \%$ de nitrato de Prata $\left(\mathrm{AgNO}_{3}\right)$. A utilização de reações de PCR sob condições de elevada estringência e oligonucleotídeos mais longos, com base em sequências cerne de VNTR (Número Variável de Repetições em Tandem), mostrou melhores resultados quando comparada a condições de baixa estringência e ao uso de oligonucleotídeos decâmeros. A estratégia empregada permitiu o isolamento de transcritos diferencialmente expressos em machos e fêmeas adultos de L. macrocephalus. Este estudo evidencia que modificações no método de DDRT-PCR garantem o melhor isolamento de DETs a partir de diferentes tecidos de peixes e asseguram a obtenção de dados mais sólidos relacionados a essa abordagem.
\end{abstract}

Palavras-chave: Leporinus macrocephalus, transcritos diferencialmente expressos, VNTR.

\section{Introduction}

In the last years, diverse genetic studies have focused on the analysis of differentially expressed genes (DETs Differentially Expressed Transcripts) or, in other words,

genes expressed as messenger RNAs (mRNA) which differ in abundance among cell types or specific tissues, and which may be regulated by chemical, physiological, 
and environmental mechanisms (Liang and Pardee, 1995). These studies allow gene characterization and evaluation of transcript expression levels in relation to extrinsic factors. Therefore, it is possible to compare samples isolated at different developing stages, collected from different environments, or from different tissues or genders (Cervigni et al., 2008; Elis et al., 2008; Kavar et al., 2008; Alves-Costa and Wasko, 2010; Woo and Yum, 2011; Kumar et al., 2013; Dhorne-Pollet et al., 2013).

A large number of methods have been used to isolate and characterize DETs, and DD (Differential Display) (Liang and Pardee, 1992) represents one of the most popular techniques concerning this approach. The DD methodology has been widely used in differential expression studies since it shows high efficiency and is characterized for its simplicity, reduced cost and for not requiring any previous knowledge about the target genome (Liang and Pardee, 1992). The large applicability of this technique may be proven by more than 16,500 published articles, describing the use of this method (Medline 2013, January - PubMed, NCBI Web site http://www.ncbi.nlm.nih.gov/entrez/query. fcgi?db=PubMed). Moreover, the differential display can simultaneously visualize increased or decreased expression of numerous mRNAs from many samples, and requires relatively small amounts of starting material (Pardee and McClelland, 1999).

Although DD also has some disadvantages, as the possibility of isolation "false-positive" transcripts (PCR products that appear to be differentially expressed on the gel but that cannot be verified when subsequent expression analyses are performed) (McClelland et al., 1995; Liang, 1998; Pardee and McClelland, 1999), technical improvements can increase its successful application. For that reason, modifications like the use of tailored primers to amplify members of a particular gene family (Jurecic et al., 1996), optimization of annealing temperature (Malhotra et al., 1998), and primer design, including the use of singleprimer correction and an annealing control primer (ACP) system (Graf et al., 1997; Kim et al., 2008, Kim et al., 2010; Ma et al., 2011), have been suggested.

Despite polymerase chain reaction (PCR)-based mRNA differential display has been widely used for identifying differentially expressed transcripts in a variety of species (e.g. Liang, 2002), some animals, as fishes, generally show a few data related to this approach. The majority of differential gene expression studies in fish species, through the use of DD, are restricted to North American and European species, or to commercial fishes, as Salmoniformes, which claim to generate important results to fish farming (Parrington and Coward, 2002). In this way, studies related to South American species are poorly exploited. Besides, works describing conditions to improve the results of fish DD are still required in this animal group. Dakis and Kouretas (2002), for example, have described some modifications in the DD technique applied to fish samples, which were characterized using a combination of longer arbitrary primers (25 and 26-mer) together with 30-mer anchored primer for PCR reactions, and the use of a nondenaturing polyacrylamide gel to analyze PCR products.

Thereby, the present work describes some different modifications of the DD technique in order to improve the results of this method in relation to DETs isolation in fish species. In an attempt to achieve this goal, we applied a DDRT-PCR approach for mRNA screening in brain tissues of Leporinus macrocephalus (piauçu), a large commercially exploited South American fish species. The improved approach permitted the isolation of differentially expressed transcripts in adult males and females of this species.

\section{Material and Methods}

\subsection{Animal samples and RNA isolation}

Adult specimens of Leporinus macrocephalus (Characiformes, Anostomidae) were obtained from a private fishery station in São Paulo State, Brazil (Kabeya Fishery Station, municipality of Glicério), where they were maintained at $25{ }^{\circ} \mathrm{C}$, and with constant aeration, until collection of brain tissues. As there is no genomic data for L. macrocephalus, the particular choice of this fish species was mainly due to the principle that the DD methodology does not require a previous knowledge on the mRNA sequences of the target biological samples. Brain tissue samples (including medulla, cerebellum, optic lobes, pineal gland, pituitary gland, cerebral hemispheres, and olfactory lobes) of 5 males and 5 females were collected and immediately stored at $-80^{\circ} \mathrm{C}$ until RNA extraction.

Approximately $100 \mathrm{mg}$ of the brain samples were mechanically homogenized with $1 \mathrm{~mL}$ of TRizol Reagent (Invitrogen ${ }^{\mathrm{TM}}$ ) and total RNA extraction followed the manufacturer's protocol. RNA samples were eluted in RNase-free water and quantified (NanoDrop 1000 Spectrophotometer) by measuring the optical density (OD) at $260 \mathrm{~nm}$. RNA purity was ensured by obtaining a $260 / 280 \mathrm{~nm}$ OD ratio $\geq 1.80$, and its integrity was ensured by agarose gels electrophoresis.

\subsection{DDRT-PCR approaches}

Total RNA samples obtained from each male and female were incubated with DNase I to remove DNA contamination, which represents a further source of falsepositive bands that can be observed on differential display gels. After DNase treatment, small aliquots of each sample were loaded onto an agarose gel to check for RNA integrity. Subsequently, $2 \mu \mathrm{g}$ high-quality RNA samples were used to prepare RNA pools of males and females, separately, in order to avoid the detection of interindividual variations not related to differences between sexes. The RNA pools were reverse transcribed (RT-PCR), separately, with the commercial kit SuperScript First-Strand Synthesis System for RT-PCR (Invitrogen ${ }^{\mathrm{TM}}$ ) using an oligonucleotide $(\mathrm{dT})_{12-18}\left(\right.$ Invitrogen $\left.^{\mathrm{TM}}\right)$ as an anchor primer, according to the manufacturer's instructions.

The cDNA samples were amplified using as single primers some oligonucleotides with 14-24 bp 
that were designed based on VNTR core sequences (primers INS: 5'-ACAGGGGTGTGGGG-3', HBV3: 5'-GGTGAAGCACAGGTG-3', HBV5: 5'-GGTGTAGAGAGGGGT-3', EMBL: 5'-AGAGCTTCAGGCTGGGCAGCTAAG-3', YNZ22: 5'-CTCTGGGTGTCGTGC-3', and FvIIex8: 5'-ATGCACACACACAGG-3'), and also RAPD (Randomly Amplified Polymorphic DNA) decamer primers (primers 1, 2, 3, 4, and 5 of the OPP series - Operon Technologies Inc.) (Alves-Costa and Wasko, 2010; Alves-Costa et al., 2012). Each cDNA amplification reaction consisted of $2 \mu \mathrm{L}$ of cDNA (10\%), $0.2 \mathrm{mM}$ of primer, 1 x $25 \mathrm{mM} \mathrm{MgCl}_{2}$ PCR buffer, $0.2 \mathrm{mM}$ of dNTPs, and $0.2 \mathrm{U}$ of Platinum Taq DNA polymerase (Invitrogen ${ }^{\mathrm{TM}}$ ), in a final volume of $50 \mu \mathrm{L}$. Reactions using the 14-24 bp primers were carried out with an initial denaturation step at $94^{\circ} \mathrm{C}$ for 2 minutes, followed by 40 cycles at $94{ }^{\circ} \mathrm{C}$ for 50 seconds, $55^{\circ} \mathrm{C}$ for 2 minutes, and $72{ }^{\circ} \mathrm{C}$ for 50 seconds, with an additional extension step at $72{ }^{\circ} \mathrm{C}$ for 5 minutes. Reactions using the 10 -mer primers were carried out with an initial denaturation step at $95^{\circ} \mathrm{C}$ for 5 minutes, followed by 45 cycles at $94{ }^{\circ} \mathrm{C}$ for 1 minute, $36^{\circ} \mathrm{C}$ for 1 minute, and $72{ }^{\circ} \mathrm{C}$ for 2 minutes, following the manufacturer's instructions of the Kit ReadyTo-Go RAPD Analysis Beads (GE Healthcare Biosciences).

DDRT-PCR products $(10 \mu \mathrm{L})$ were fractionated on $6 \%$ polyacrylamide gels stained with $0.17 \%$ Silver Nitrate $\left(\mathrm{AgNO}_{3}\right.$ ) (Sambrook and Russel, 2001), and visualized under white light. The molecular weigh of the amplified fragments was assigned through comparison with a $1 \mathrm{~Kb}$ DNA ladder (Invitrogen ${ }^{\mathrm{TM}}$ ).

\section{Results and Discussion}

Preliminary analyses were performed to determine primers that provide superior and reproducible amplification results. As so, cDNA amplification was achieved using decamer oligonucleotides commonly used in RAPD analyses and also oligonucleotides that were designed based in VNTR core sequences that correspond to minisatellite short and highly conserved regions (Jeffreys et al., 1985). The use of the 10 -mer primers, that commonly generate multiple bands for different organisms (Lee et al., 2001; Yang et al., 2004; Zhang et al., 2008), did not produce this type of amplification pattern for brain tissues of L. macrocephalus. Moreover, the amplification reactions usually resulted on several faint and diffuse bands, and the results were generally not reproducible (Figure 1). These faint bands often lead to a misinterpretation of the data. In addition, just a reduced number of candidate differentially expressed transcripts could be identified when comparing males and females of L. macrocephalus through the use of RAPD primers (Figure 1).

The use of longer primers on differential display strategies may also lead to detection of DNA polymorphism through RAPD-like results. Some studies evidenced that primers with 13 bases or longer have better effects in the DD efficiency (Zhao et al., 1995; Liang, 1998; Motlik et al., 1998; Huang et al., 2001; Alves-Costa and Wasko, 2010;

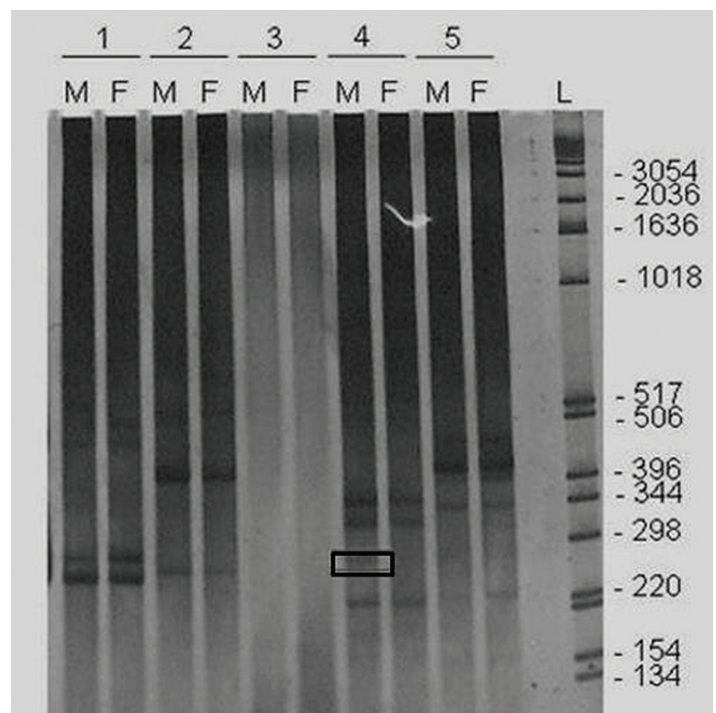

Figure 1. DDRT-PCR fingerprints on a $6 \%$ polyacrylamide gel stained with $\mathrm{AgNO}_{3}$. The molecular weight of the amplified fragments (using decamer primers) was assigned through comparison with a $1 \mathrm{~Kb}$ DNA Ladder (Invitrogen ${ }^{\mathrm{TM}}$ ), indicated on the right side (L). (1) primer 1, (2) primer 2, (3) primer 3, (4) primer 4, and (5) primer 5 of the OPP series (Operon Technologies Inc.). $\mathbf{M}=$ pool of RNA male samples; $\mathbf{F}=$ pool of RNA female samples. A single amplified fragment that may correspond to a differentially expressed transcript is highlighted (box).

Alves-Costa et al., 2012). As the oligonucleotides of VNTR core sequences (14-24 bp), used as single primers to amplify the cDNA samples of $L$. macrocephalus, are longer than RAPD primers, the methodology could be effectively carried out at a relatively high stringency, thus yielding enhanced results - the generated bands were more distinct and the results of cDNA amplification were consistently repeatable (Figure 2). These data are consistent with the proposal that DDRT-PCR reactions need special adjustments for each species samples since its fingerprinting patterns may vary from one cell type to another (Blaes et al., 2007).

Despite this optimization in the DD approach in brain tissues of a fish species, our results led to the identification of a restricted number of amplification products, even using longer primers. The DD methodology generally leads to the visualization of 5 to 100 amplification products in polyacrylamide gel (McClelland et al., 1995). The unworkable achievement of a complex amplification pattern with a high number of bands can be due to the high PCR stringency conditions, through an annealing temperature of $55^{\circ} \mathrm{C}$, or to the use of RNA sample pools that can avoid the detection of individual variations. Despite the relative reduced number of amplified fragments (around 5 to 15 bands) visualized on polyacrylamide gels, some of them could be detected only in males or females, which indicate that they correspond to presumptive differentially expressed transcripts between the two samples. Thirty 


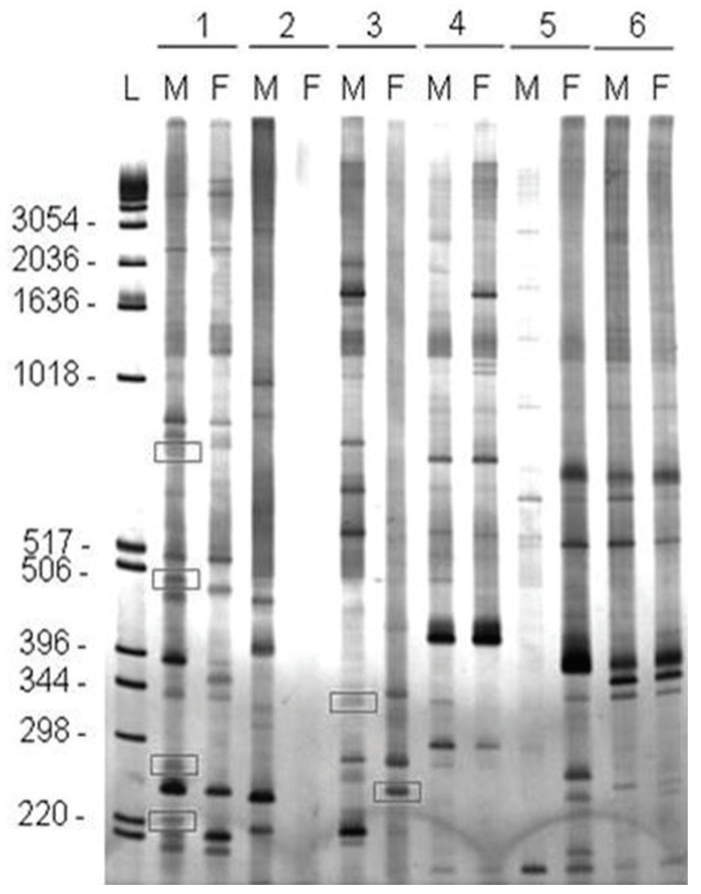

Figure 2. DDRT-PCR fingerprints on a $6 \%$ polyacrylamide gel stained with $\mathrm{AgNO}_{3}$. The molecular weight of the amplified fragments (using longer primers, based on VNTR core sequences) was assigned through comparison with a $1 \mathrm{~Kb}$ DNA Ladder (Invitrogen ${ }^{\mathrm{TM}}$ ), indicated on the left side (L). (1) primer INS, (2) primer HBV3, (3) primer HBV5, (4) primer EMBL, (5) primer YNZ22, and (6) primer FvIIex8. $\mathbf{M}=$ pool of male RNA samples; $\mathbf{F}=$ pool of female RNA samples. The single amplified fragments that may correspond to differentially expressed transcripts are highlighted (boxes).

one cDNAs appeared to be differentially expressed on males and females of $L$. macrocephalus. Therefore, the improved DD approach using VNTR core sequences as primers in RT-PCR led to the identification of putative sex differentially expressed transcripts in this fish species and may be used as a strategy in future studies related to this approach in order to obtain consistent data.

\section{Acknowledgements}

The authors thank FAPESP (Fundação da Amparo à Pesquisa do Estado de São Paulo) and CNPq (Conselho Nacional de Desenvolvimento Científico e Tecnológico) for finnancial supports.

\section{References}

ALVES-COSTA, FA. and WASKO, AP., 2010. Identification of sexually dimorphic gene expression in brain tissue of the fish Leporinus macrocephalus through mRNA differential display and real time PCR analyses. Genetica, vol. 138, no. 3, p. 321-331. http://dx.doi.org/10.1007/s10709-009-9421-8. PMid:19890727
ALVES-COSTA, FA., FIGUEIREDO, MA., LANES, CFC., ALMEIDA, DV., MARINS, LF. and WASKO, AP., 2012. A comparative expression analysis of gene transcripts in brain tissue of non-transgenic and GH-transgenic zebrafish (Danio rerio) using a DDRT-PCR approach. Anais da Academia Brasileira de Ciencias, vol. 84, no. 2, p. 487-494. http://dx.doi.org/10.1590/ S0001-37652012005000033. PMid:22584411

BLAES, N., ELBAZ, M., HEITZ, F., CAUSSÉ, E., GLOCK, Y., PUEL, J. and BAYARD, F., 2007. Differential display fingerprints: new approach to characterize smooth muscle cells and human coronary atherectomy tissues. Pathologie Biologie, vol. 55, no. 7, p. 328-335. http://dx.doi.org/10.1016/j.patbio.2007.05.006. PMid:17611041

CERVIGNI, GDL., PANIEGO, N., PESSINO, S., SELVA, JP., DÍAZ, M., SPANGENBERG, G. and ECHENIQUE, V., 2008. Gene expression in diplosporous and sexual Eragrostis curvula genotypes with differing ploidy levels. Plant Molecular Biology, vol. 67, no. 1-2, p. 11-23. http://dx.doi.org/10.1007/s11103-0089305-9. PMid: 18311543

DAKIS, D. and KOURETAS, D., 2002. Differential display of $\mathrm{m}$-RNAs in fish gonads by modified DD-PCR. In Vivo (Athens, Greece), vol. 16, no. 2, p. 103-105. PMid:12073767.

DHORNE-POLLET, S., THÉLIE, A. and POLLET, N., 2013. Validation of novel reference genes for RT-qPCR studies of gene expression in Xenopus tropicalis during embryonic and post-embryonic development. Developmental dynamics : an official publication of the American Association of Anatomists, vol. 242, no. 6, p. 709-717. http://dx.doi.org/10.1002/dvdy.23972. PMid:23559567

ELIS, S., BATELliER, F., COUTY, I., BALZERGUE, S., MARTIN-MAGNIETTE, ML., MONGET, P., BLESBOIS, E. and GOVOROUN, MS., 2008. Search for the genes involved in oocyte maturation and early embryo development in the hen. $B M C$ Genomics, vol. 9, no. 1, p. 110. http://dx.doi.org/10.1186/14712164-9-110. PMid:18312645

GRAF, D., FISHER, AG. and MERKENSCHLAGER, M., 1997. Rational primer design greatly improves differential display-PCR (DD-PCR). Nucleic Acids Research, vol. 25, no. 11, p. 22392240. http://dx.doi.org/10.1093/nar/25.11.2239. PMid:9153330

HUANG, YJ., LI, Y., SHI, M., WANG, JA., HU, MR. and SHEN, BF., 2001. Isolation of genes related with IL-6 effect by a rapid and simple RT-PCR method. Progress in Biochemistry and Biophysics, vol. 28, p. 563-567.

JEFFREYS, AJ., WILSON, V. and THEIN, SL., 1985. Hypervariable 'minisatellite' regions in human DNA. Nature, vol. 314, no. 6006, p. 67-73. http://dx.doi.org/10.1038/314067a0. PMid:3856104

JURECIC, R., NGUYEN, T. and BELMONT, JW., 1996. Differential mRNA display using anchored oligo-dT and long sequence-specific primers as arbitrary primers. Trends in genetics: $T I G$, vol. 12, no. 12, p. 502-504. http://dx.doi.org/10.1016/S01689525(96)90045-1. PMid:9257529

KAVAR, T., MARAS, M., KIDRIC, M., SUSTAR-VOZLIC, J. and MEGLIC, V., 2008. Identification of genes involved in the response of leaves of Phaseolus vulgaris to drought stress. Molecular Breeding, vol. 21, no. 2, p. 159-172. http://dx.doi. org/10.1007/s11032-007-9116-8.

KIM, TW., KIM, HJ., LEE, C., KIM, HY., BAEK, SH., KIM, JH., KWON, KS. and KIM, JR., 2008. Identification of replicative senescence-associated genes in human umbilical vein endothelial cells by an annealing control primer system. Experimental 
Gerontology, vol. 43, no. 4, p. 286-295. http://dx.doi.org/10.1016/j. exger.2007.12.010. PMid:18258400

KIM, YS., HWAN, JD., BAE, S., BAE, DH. and SHICK, WA., 2010. Identification of differentially expressed genes using an annealing control primer system in stage III serous ovarian carcinoma. BMC Cancer, vol. 10, no. 1, p. 576. http://dx.doi. org/10.1186/1471-2407-10-576. PMid:20969748

KUMAR, RR., SHARMA, SK., GOSWAMI, S., SINGH, GP., SINGH, R., SINGH, K., PATHAK, H. and RAI, RD., 2013. Characterization of differentially expressed stress-associated proteins in starch granule development under heat stress in wheat (Triticum aestivum L.). Indian Journal of Biochemistry \& Biophysics, vol. 50, no. 2, p. 126-138. PMid:23720887.

LEE, KF., CHOW, JF., XU, JS., CHAN, ST., IP, SM. and YEUNG, WS., 2001. A comparative study of gene expression in murine embryos developed in vivo, cultured in vitro, and cocultured with human oviductal cells using messenger ribonucleic acid differential display. Biology of Reproduction, vol. 64, no. 3, p. 910-917. http://dx.doi.org/10.1095/biolreprod64.3.910. PMid:11207208

LIANG, P., 1998. Current progress in differential display methods and applications. In LIANG, P. (Ed.). Methods: A Companion to Methods in Enzymology. New York: Academic Press. p. 365375. vol. 16

LIANG, P., 2002. A decade of differential display. BioTechniques, vol. 33, no. 2, p. 338-344, 346. PMid:12188186.

LIANG, P. and PARDEE, AB., 1992. Differential display of eukaryotic messenger RNA by means of the polymerase chain reaction. Science, vol. 257, no. 5072, p. 967-971. http://dx.doi. org/10.1126/science.1354393. PMid:1354393

LIANG, P. and PARDEE, AB., 1995. Recent advances in differential display. Current Opinion in Immunology, vol. 7, no. 2, p. 274-280. http://dx.doi.org/10.1016/0952-7915(95)80015-8. PMid:7546389

MA, J., WANG, PW., YAO, D., WANG, YP., YAN, W. and GUAN, SC., 2011. Single-primer PCR correction: a strategy for falsepositive exclusion. Genetics and molecular research: GMR, vol. 10, no. 1, p. 150-159. http://dx.doi.org/10.4238/vol10-1 gmr988. PMid:21308656

MCCLELLAND, M., MATHIEU-DAUDE, F. and WELSH, J., 1995. RNA fingerprinting and differential display using arbitrarily primed PCR. Trends in genetics: TIG, vol. 11, no. 6, p. 242-246. http://dx.doi.org/10.1016/S0168-9525(00)89058-7. PMid:7543710

MALHOTRA, K., FOLTZ, L., MAHONEY, WC. and SCHUELER, PA., 1998. Interaction and effect of annealing temperature on primers used in differential display RT-PCR. Nucleic Acids Research, vol. 26, no. 3, p. 854-856. http://dx.doi.org/10.1093/ nar/26.3.854. PMid:9443980

MOTLIK, J., CARNWATH, JW., HERRMANN, D., TERLETSKI, V., ANGER, M. and NIEMANN, H., 1998. Automated recording of RNA differential display patterns from pig granulosa cells. BioTechniques, vol. 24, no. 1, p. 148-153. PMid:9454967.

PARDEE, AB. and MCCLELLAND, M., 1999. Expression genetics: differential display. In PARDEE, AB. and MC CLELLAND, M. (Eds.). Expression genetics: differential display. USA: Eaton Publishing. p. 1-7.

PARRINGTON, J. and COWARD, K., 2002. Use of emerging genomic and proteomic technologies in fish physiology. Aquatic Living Resources, vol. 15, no. 3, p. 193-196. http://dx.doi. org/10.1016/S0990-7440(02)01172-5.

SAMBROOK, J. and RUSSEL, DW., 2001. Molecular cloning: A Laboratory Manual. 3rd ed. New York: Cold Spring Harbor Laboratory Press. vol. 2.

WOO, S. and YUM, S., 2011. Transcriptional response of marine medaka (Oryzias javanicus) on exposure to toxaphene. Comparative biochemistry and physiology. Toxicology \& pharmacology: $C B P$, vol. 153 , no. 3, p. 355-361. http://dx.doi.org/10.1016/j. cbpc.2010.12.006. PMid:21220043

YANG, H., LI, Y., GUAN, GH. and LI, XY., 2004. [Transcriptional differences between a heterokaryon and its segregants of Fusarium oxysporum f. sp. vasinfectum]. Yi Chuan Xue Bao = Acta Genetica Sinica, vol. 31, no. 2, p. 166-170. PMid:15473307.

ZHANG, J., TURLEY, RB. and STEWART, JM., 2008. Comparative analysis of gene expression between CMS-D8 restored plants and normal non-restoring fertile plants in cotton by differential display. Plant Cell Reports, vol. 27, no. 3, p. 553-561. http:// dx.doi.org/10.1007/s00299-007-0492-7. PMid:18080126

ZHAO, S., OOI, SL. and PARDEE, AB., 1995. New primer strategy improves precision of differential display. BioTechniques, vol. 18, no. 5, p. $842-846,848,850$. PMid:7619490. 